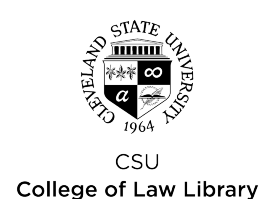

Cleveland State University

College of Law Library

\title{
EngagedScholarship@CSU
}

1997

\section{Responsibilities of Employers toward Mentally Disabled Persons under the Americans with Disabilities Act}

Karin M. Mika

Cleveland State University, k.mika@csuohio.edu

Denise Wimbiscus

Follow this and additional works at: https://engagedscholarship.csuohio.edu/fac_articles

Part of the Civil Rights and Discrimination Commons, Labor and Employment Law Commons, and the Litigation Commons

How does access to this work benefit you? Let us know!

\section{Original Citation}

Karin Mika, Responsibilities of Employers toward Mentally Disabled Persons under the Americans with Disabilities Act, 11 Journal of Law and Health 173 (1996-97)

This Article is brought to you for free and open access by the Faculty Scholarship at EngagedScholarship@CSU. It has been accepted for inclusion in Law Faculty Articles and Essays by an authorized administrator of EngagedScholarship@CSU. For more information, please contact research.services@law.csuohio.edu. 


\section{HEINONLINE}

Citation: 11 J.L. \& Health 173 1996-1997

Content downloaded/printed from

HeinOnline (http://heinonline.org)

Fri May 18 09:29:44 2012

-- Your use of this HeinOnline PDF indicates your acceptance of HeinOnline's Terms and Conditions of the license agreement available at http://heinonline.org/HOL/License

-- The search text of this PDF is generated from uncorrected OCR text.

-- To obtain permission to use this article beyond the scope of your HeinOnline license, please use:

https://www.copyright.com/ccc/basicSearch.do?

\&operation $=$ go\&search Type $=0$

\&lastSearch $=$ simple\&all=on\&titleOrStdNo=1044-6419 


\title{
RESPONSIBILITIES OF EMPLOYERS TOWARD MENTALLY DISABLED PERSONS UNDER THE AMERICANS WITH DISABILITIES ACT
}

\author{
KARIN MIKA ${ }^{1}$ \\ DENISE WIMBISCUS ${ }^{2}$
}

I. Mental Illness in General $\ldots \ldots \ldots \ldots \ldots \ldots \ldots \ldots 174$

II. The Legal Definition of Mental Disability . . . . . . . . 175

III. When Must an Employer be on Notice of a

Mental Disability? . . . . . . . . . . . . . . . . . 179

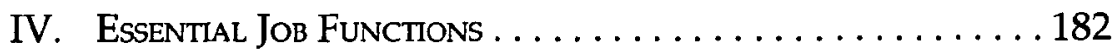

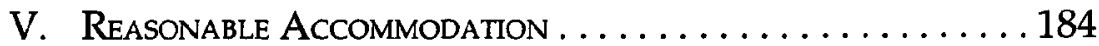

VI. OTHerwise Qualified $\ldots \ldots \ldots \ldots \ldots \ldots \ldots \ldots \ldots \ldots \ldots$

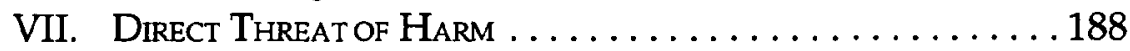

VIII. The Future of MENTAL Disabilities Under the ADA:

Suggestions for Change . . . . . . . . . . . . . . . 189

IX. Conclusion ........................ 193

Proclaimed as "ultimately a civil rights bill," 3 the Americans with Disabilities Act $^{4}$ extended protection of civil rights within the employment sphere for persons with physical and mental disabilities. ${ }^{5}$ At the same time, the legislation encouraged the integration of persons with disabilities within the workplace. 6 While the Americans with Disabilities Act incorporates the language of its predecessor, the Rehabilitation Act of 1973,7 neither Act contains any statutory

1B.A., Baldwin-Wallace College (1986); J.D., Cleveland-Marshall College of Law (1989). Assistant Director of Legal Writing, Research \& Advocacy at Cleveland-Marshall College of Law.

2B.A., University of Notre Dame (1985); J.D., Cleveland-Marshall College of Law (1995). Litigation Manager of United Financial Casualty Company of Progressive Insurance Company.

${ }^{3}$ H.R. Rep. No. 485(I), 101st Cong., 2d Sess. 25 (1990).

442 U.S.C. $\$ \S 12101-12213$ (1990)(hereinafter the Act or ADA).

5 William Stein, A New Bill of Rights for Millions: the Americans with Disabilities Act of 1990, 46 ARB. J. 6, 6 (1991).

6H.R. Rep. No. 485(II), 101st Cong., 2d Sess. 58 (1990).

729 U.S.C. $\$ \$ 701-796$ (1985). The Federal Rehabilitation Act prohibits employment discrimination against disabled individuals by all employers receiving federal funds. In comparison, the ADA applies to all employers with fifteen or more employees whether or not they receive federal funds. 42 U.S.C. $\S 12111(5)(A)(1990)$. 
specifics that address the difficulties of dealing with mental illness in the workplace. Because the Americans with Disabilities Act is vague with respect to accommodating mental illness and because mental illness itself is often part of uncertain science, the rights and responsibilities of employers dealing with alleged or perceived mental illness are also uncertain. One of the areas that is most problematic for an employer when making promotion and retention decisions is making promotion and retention decisions that comport with their legal obligations. Employers raise legitimate concerns about what are their rights in making employment decisions, especially in light of their duty under the Americans with Disabilities Act as well as their interest in maintaining a profitable, efficient business.

This article will discuss the standards of the ADA with respect to accommodating mental illness in the workplace. It will argue the ADA definitions are not precise enough in apprising employers of what are their obligations regarding mentally ill persons in the workplace. It will additionally make suggestions for revising the statute and regulations to achieve this goal. In reaching its conclusion, this article will discuss popular conceptions about mental illness, and the current statutory framework of the ADA. Representative case law will be considered within the context of these topics. The article will ultimately suggest that fairness to both employers and employees can only be achieved by clearer definitions within the statute and an overt acknowledgment that mental disabilities are not necessarily synonymous with physical disabilities.

\section{MENTAL ILLNESS IN GENERAL}

The medical definition of "mental illness," in many respects, differs from the popular understanding of the term. 8 Popular culture often associates mentally ill as synonymous with insanity "with the result" being a crazed and uncontrolled behavior. ${ }^{9}$ This picture may conjure images of straitjackets, forced sedation electroshock therapy.10 Popular culture does not always associate mental illness with depression or alcoholism-legitimate mental health disorders that do not always substantially affect day-to-day functioning, and, in fact, are quite prevalent in our society. 11

8 See John Lagos, et. al., Fear of the Mentally Ill: Empirical Support for the Common Man's Response, 134 AM J. PsYCHATRY 1134, 1134 n.1 (1977).

${ }^{9}$ See Leonard S. Rubenstein, Ending Discrimination Against Mental Health Treatment in Publicly Financed Health Care, 40 ST. Lous U. L.J. 315, 349-51 (1996).

${ }^{10}$ Hollywood often creates and perpetuates myths and stereotypes about mental illness. See Otto F. Wahl, Media Madness: Public Images of Mental Illness, VANCOUVER SUN, Apr. 20, 1996, at D14.

11 "The most common psychiatric disorders [are] major depression and alcohol dependence." See John D. Thompson, Psychiatric Disorders, Workplace Violence and the Americans with Disabilities Act, 19 HAMLINE L. REV. 25, 26 (1995). 
Mental health professionals themselves disagree as to whether personality disorders, alcohol abuse, and substance abuse are properly characterized as mental illness or personality flaws. 12 There is also a debate as to whether gender-related conditions such as menopause and premenstrual syndrome are substantially "life-impairing" such that they too might require legal accommodation as mental illnesses under the federal statute. ${ }^{13}$ In addition, there are some organic disorders, such as mental retardation and Alzheimer's disease, that are both physical and mental disabilities. 14

Mental health professionals as a whole struggle with where drawing the line between normal and abnormal behavior. 15 The conglomerate of mental health professionals share many common methods of diagnosing "mentally ill" patients, but often disagree on ultimate assessments and modes of treatments. ${ }^{16}$ The tool most widely used by mental health professionals is the Diagnostic and Statistical Manual of Mental Disorders (DSM), produced by the American Psychiatric Association as an attempt at uniform diagnosis within the profession. 17 Now in its fourth revision, the DSM-IV, like its three predecessors, has been criticized because of its complexity and because it is more of an encyclopedia of classification rather than a diagnostic tool. 18 The current DSM validates the reality that there are many uncertain aspects of behavioral study.

\section{THE LEgal DEFINITION OF MENTAL DisabiLITY}

One of the difficulties of eliminating employment discrimination against persons with mental disabilities is recognizing what is a mental disability requiring accommodation under federal law. Many mental disabilities are not

12Menachem Krakowski, et al., Psychopathology and Violence: A Review of Literature, 27 COMPREHENSIVE PSYCHOL. 131 (1986).

13 See Lee Solomon, Colloquium: Gender, Law, and Health Care: Premenstrual Syndrome: The Debate Surrounding Criminal Defense, 54 MD. L. REV. 571 (1995)(commenting on the addition of premenstrual dysphoric disorder to the list of depressive disorders in the DSM-IV).

14 See, e.g., Anne DesNoyers Hurley, Identifying Psychiatric Disorders in Persons with Mental Retardation: A Model lllustrated by Depression in Down Syndrome, 62 J. REHAB. 27 (1996).

15Theodore Lidz, et al., Letters to the Editor, 151 AM J. PSYCHIATRY 458-59 (1994).

16There are various professions regarded as being within the realm of "mental health professionals." The DSM-IV lists, among others, psychiatrists, psychologists, social workers, occupational and rehabilitation therapists, and counselors. AMERICAN PSYCHIATRIC ASSOCIATION, DiagNOSTIC ANDSTATISTICAL MANUAlOF MENTAL DisORDERS xv (4th ed. 1994).

${ }_{17}$ Id.; see also Aya V. Matsumoto, Reforming the Reform: Mental Stress Claims Under California's Workers' Compensation System, 27 LOY. L.A. L. REV. 1327, 1346-47 (1994).

18 Herb Kutchins \& Stuart A. Kirk, DSM-IV: Does Bigger Mean Better? HARV. MENTAL. HeALTH LetTER, May 1, 1995. 
visible or readily apparent to most observers and still may warrant protection under the ADA if properly diagnosed; 19 however, definitions of some types of mental disabilities under the ADA are not precise enough to make clear the persons who are intended to benefit from the Act's protection. The statute grants protection to those having a "mental impairment that substantially limits one or more of the major life activities of such individual."20 The Code of Federal Regulations supplements this definition by adding, "any mental or psychological disorder, such as mental retardation, organic brain syndrome, emotional or mental illness, and specific learning disabilities."21 There is no comprehensive list as to what emotional or mental illnesses were contemplated by the legislature, and recognized "legal" mental disabilities are established on a case-by-case basis. 22

Under both the Rehabilitation Act and the ADA, individuals may meet the definition of "handicapped" or "disabled" in three different ways. 23 The first is that the person must have an actual physical or mental impairment that "substantially limits one or more major life activities."24 The second is that the person has a "record" of such an impairment; 25 for instance, the person has been previously hospitalized for the disorder. ${ }^{26}$ The third way is to be regarded "as having such an impairment"27-sometimes described as "having been treated as handicapped," or discriminated against because of "unsubstantiated

${ }^{19}$ See, e.g., Collins v. Blue Cross Blue Shield, 916 F. Supp. 638 (E.D. Mich. 1995).

2042 U.S.C. $\$ 12102(2)(A)$ (West 1995).

2129 C.F.R. $\$ 1630.2(h)(2)$ (1996).

22 Among the illnesses recognized under the Rehabilitation Act are depression, manic-depression, depressive neurosis, paranoid schizophrenia, post-traumatic stress disorder, and bi-polar disorder. Thompson, supra note 11, at fns. 78, 80, 82 (citing respectively Pesterfield v. Tennessee Valley Auth., 941 F.2d 437 (6th Cir. Tenn. 1991); Gardner v. Morris, 752 F.2d 1271 (8th Cir. Mo. 1985); Doe v. Region 13 Mental Health-Mental Retardation Comm., 704 F.2d 1402 (5th Cir. Miss. 1983); Franklin v. United States Postal Serv., 687 F. Supp. 1214 (S. D. Ohio 1988); Schmidt v. Bell, 1 Am. Disabilities Cas. (BNA) 491 (E.D. Pa. 1983); Fields v. Lyng, 705 F. Supp. 1134 (D. Md. 1988).

${ }^{23}$ The Rehabilitation Act of 1973, predecessor to the ADA, was intended by Congress to make the federal government into a "model employer of handicapped individuals" by eliminating employment discrimination against persons with physical and mental disabilities. See Whitlock v. Donovan, 598 F. Supp. 126 (D.D.C. 1984). The Congressional debate prior to the enactment of the ADA reflect Congress's consideration and approval of interpretive case law developed under the Rehabilitation Act. H.R. Rep. No. 485(II), 101st Cong., 2d Sess. 50-54 (1991).

2429 U.S.C. $\S 706(8)(B)$ (1996); see also 42 U.S.C. $§ 12102(2)(A)$ (West 1995).

25 Id.

26 See, e.g., Pridemore v. Legal Aid Soc'y, 625 F. Supp. 1171 (S.D. Ohio 1985).

27 Id. 
concerns." 28 Those meeting one of the definitions must be qualified for the job which they "hold or desire." 29 Any accommodation for the person must be "reasonable" for the employer to make. ${ }^{30}$ In this definitional section, the Act makes no distinction between physical and mental impairments.

Congress articulated a desire for the ADA to provide better standards for application than did the Rehabilitation Act. ${ }^{31}$ Section 12101(b)(2) of the ADA expressly states that the purpose of the legislation is to develop "clear, strong, consistent, enforceable standards" for preventing employment discrimination with respect to those disabilities articulated. To accomplish this purpose, Congress instructed the Equal Employment Opportunity Commission (EEOC) to formulate final instructive regulations within one year of the implementation of the Act. ${ }^{32}$ The interpretative guidelines for the portions of the statute dealing with Mental Disabilities is included in the Code of Federal Regulations as an appendix to Section 1630. The EEOC has also issued "technical assistance manuals" for Parts I, II, and III of the Americans with Disabilities Act. 33

The "Interpretive Guidance" of the EEOC mirrors the Rehabilitation Act regulations. Both specify that "mental impairment" is "any mental or psychological disorder." 34 However, under the interpretive guidelines, a distinction is made between behaviors that are merely the result of undesirable personality traits as opposed to behaviors that are symptoms of a mental or psychological disorder. ${ }^{35}$ The guidelines and the corresponding federal regulations specifically exclude from their definitions persons with disorders stemming from current illegal drug use. 36

Once the existence of a protected "impairment" is established, the individual must demonstrate that he or she is "otherwise qualified" for the job.37 Qualification is measured by whether the person has the appropriate educational background, skills, and experience. ${ }^{38}$ If so, the person must be able

28 See, e.g., School Bd. of Nassau County v. Arline, 480 U.S. 273 (1987); Pushkin v. Regents of University of Colo., 658 F.2d 1372 (10th Cir. 1987).

2942 U.S.C. $\$ 12111(8)$ (West 1995).

3042 U.S.C. $\$ 12111$ (a) (West 1995).

31 See, e.g., A \& P ADA Comm. Print (28C) 1913-14 (1990).

32See 29 C.F.R. $§ 1601.1$ (1996).

33 Thompson, supra note 11, at n. 59.

34 See 29 C.F.R. § 1630, App. (1996).

35 Id.

3629 C.F.R. $§ 1630$, App. (1996); see also 29 C.F.R. 1630.3(a)-(c) (1996).

3729 C.F.R. § 1630.2(l)(1)(m) (1996).

38 Id. 
to perform "essential job functions," 39 as opposed to marginal functions, with or without reasonable accommodation provided by the employer. ${ }^{40} \mathrm{~A}$ qualified person with a disability must request an accommodation from the employer who then has the option to choose the mechanism for the accommodation from among any available "reasonable" altematives. 41 The ADA does not allow pre-employment inquiries into medical history. 42

Daley $v . K^{\prime}$ ch $^{43}$ is the leading case dealing with the distinction between general character or behavioral traits that are undesirable as distinguished from behavior symptomatic of an abnormal mental condition. In Daley, the employee applied for a position as a police officer. The application process required the employee to submit to psychological testing. ${ }^{44}$ The testing revealed that the employee exhibited "poor judgment, irresponsible behavior and poor impulse control." 45 As a result of the testing, he was denied the position. The employee then filed a discrimination claim under the Rehabilitation Act, charging that he was denied the position because of his mental disability. 46 The court refused to recognize the claim, holding that commonplace personality traits do not rise to the level of impairment intended by Congress to be protected. No further evidence was presented by the plaintiff-employee to show that he had been diagnosed with mental illness or a mental disorder. The court did not consider a personality shortcoming to fall within the protections of the statute. 47

In another case decided under the Rehabilitation Act, the employee also failed to meet the threshold requirement of possessing a legally recognized disability. Butler $v$ Department of Navy 48 involved a National Naval Medical Center warehouse worker who had a very poor attendance record during his time on the job. When he did report to work, he failed to follow orders and took unauthorized breaks. At one point, he physically threatened his supervisor

${ }^{39} 29$ C.F.R. $\S 1630.2(n)(1)-(3)(1996)$.

4029 C.F.R. $\S 1630.2(\mathrm{~m})$ (1996).

41 See Baxter v. Wisconsin Dep't. of Natural Resources, 477 N.W.2d 648 (Wis. Ct. App. 1991) (procuring a "job coach" for a depressed person held not mandatory).

4242 U.S.C. $\$ 12112$ (d) (West 1995); see also H.R. Rep. No. 485(II) 101st Cong., 2d Sess., $42-43$ (1990). This has immense consequences in the realm of employment decisions dealing with potential mental disabilities. Since employers dealing with persons with disabilities will not be able to readily observe the disability, as a practical matter, the employee would have to disclose the condition to the employer in order to be accommodated.

43892 F.2d 212 (2d Cir. N.Y. 1989).

44 Id. at 213.

45 Id. at 214.

46 Id.

47892 F.2d at 215-16.

48595 F. Supp. 1063 (D. Md. 1984). 
stating that "he didn't want to hear anything from [him]," believing his supervisor should not "dictate" to him. 49 The plaintiff was terminated by the employer within one year of his hire date. In response to his firing, the employee charged the Navy with failure to make reasonable accommodation for his "handicap." 50 In finding against the plaintiff, the court stated that an employee is not excused for misconduct or unsatisfactory performance that does not relate to a legally-recognized "handicap."51

\section{When MuSt AN EMPLOYER BE ON NOTICE OF A MeNTAL Disability?}

Although the Code of Federal Regulations suggests that it is the burden of the person seeking "accommodation" to let the employer know of a disability, 52 cases involving an alleged mental disability generally come about after the employee has been discharged without any accommodation having been sought. ${ }^{53}$ In these situations, the employee usually asserts that he/she had a mental disability that was not diagnosed during employment, but was nonetheless responsible for the behavior that resulted in discharge. Despite no accommodation being sought while employed, these plaintiffs bring causes of action under the ADA maintaining that the termination was discrimination based on disability. 54

These situations illustrate the difficulties of understanding what are the obligations of employers under the statute, especially where mental illness is concerned. In some respects it would be unfair to hold a person responsible for his/her actions when there is a legitimate mental illness; however, it is equally unfair to expect that an employer should reasonably accommodate an employee before being apprised of the problem. This is especially true since an employer is statutorily proscribed from asking about a disability that has not been disclosed.55

Another complexity for employers is interpreting the portion of the Act stating that disabled could mean "regarded as having such an impairment."56 Although this definition in the statute was originally intended to protect those

49 Id. at 1066.

$50 \mathrm{Id}$. at 1067.

51 Id.

52See 29 C.F.R. $\S 1630.9$ (a) (1996): "It is unlawful for a covered entity not to make reasonable accommodation to the known physical or mental limitations of an otherwise qualified applicant." Id.

$53 \mathrm{See}$, e.g., Office of Senate Sergeant at Arms v. Office of Senate Fair Employment Practices, 95 F.3d 1102 (Fed. Cir. 1996); Scarbrough v. Runyon, 92 F.3d 1187 (7th Cir. 1996); Beck v. University of Wis. Bd. of Regents, 75 F.3d 1130 (7th Cir. 1996).

54 Id.

5542 U.S.C. $\S 12112$ (d)(1) (West 1995).

5642 U.S.C. $§ 12102$ (2)(c) (West 1995). 
whose disability did not limit functioning,, 57 this definition has been used by employees asserting that an employer treated the employee as mentally ill. This has presumably occurred by disciplining or discharging the employee when that employee was not performing his or her job adequately.58 In other instances, the employee has asserted that the employer "should have known" that problem behavior was the result of a legitimate mental illness. 59 These cases have raised a question as to whether the employer is ever responsible for recognizing and accommodating behaviors that may be indicative of mental illness, or for being responsible when erratic behavior is noticed. There is also a conceivable issue as to whether an employer may actually be subjecting itself to a discrimination suit under the ADA when a supervisor does not care for a subordinate's personality. 60

For the most part, courts will not impose an obligation on an employer to accommodate an employee perceived to be mentally ill.61 For instance, in Pouncy v. Vulcan Materials Co., 62 the court held that an employee who had "poor behavioral traits and performance problems" was not disabled under ADA definitions. In this case, the plaintiff was not diagnosed with a mental problem, nor did she claim a mental impairment. Rather, she could not get along with any of her co-workers and had a history of a negative attitude towards her work.63 After discharge, she sought protection under the ADA because she claimed her employer "perceived a mental impairment" leading to her termination-that is, she claimed she had been "treated" as impaired and consequently discriminated against by virtue her termination. In finding for the defendant, the court determined that a perceived, undiagnosed impairment did not fall within the intended provisions coverage of the Act and the employer was not obligated under federal law to maintain her employment. 64

The EEOC's interpretive guidelines state that employers are only obligated to attempt reasonable accommodation for those employees known to be disabled, but does not specify whether "known" means medically validated. The guidelines state that, in general, it is the obligation of the disabled employee to notify the employer that an accommodation is needed. 65 It is not clear, however, whether an employer is free to inquire of an employee who

57 A\&P ADA Comm. Print (28A) 121 (1990).

58 See, e.g., Pouncy v. Vulcan Materials Co., 920 F. Supp. 1566 (N.D. Ala. 1996).

${ }^{59}$ See, e.g., Fenton v. Pritchard Corp., 926 F. Supp. 1437 (D. Kan. 1996).

60 See Thompson, supra note 11, at 55.

61 See, e.g., McIntyre v. Kroger Co., 863 F.Supp. 355 (N.D. Tex. 1994); Nuccio v. Frank, No. 91-3702 (E.D. La. June 17, 1992).

62920 F. Supp. 1566, 1580 (N.D. Ala. 1996).

63 Id. at $1573-78$.

64 Id. at $1580-81$.

6529 C.F.R. Pt. 1630, App. (1996). 
displays symptoms of mental illness as to whether an accommodation is needed. The statement in the EEOC guidelines is phrased in a manner which suggests that only those with known disabilities may be approached by the employer with a suggestion of accommodation. The guidelines also leave open the possibility that an undiagnosed disability may be "known" because it is "obvious." 66 While the regulations permit employers to require employees to submit to medical examinations when there is a need to determine whether an employee who is on-the-job is still able to perform the essential functions of the job, 67 it is unclear how this plays out when a mental disability is suspected.

The 1995 case of, Stola $v$. Joint Indus. Bd. 68 is indicative of one's court's point of view of employer's responsibility. In Stola, the plaintiff-employee was an apprentice electrician who engaged in threatening and menacing behavior, necessitating his removal from the workplace by security personnel.69 His employer terminated him as a result of this behavior. The employee claimed ADA protection because his behavior was a product of a "general anxiety" disorder, which was not diagnosed until after he was terminated. The court ruled in favor of the employer, primarily because there had been no notice of the disability. The plaintiff, in turn, asserted that he was unaware of his own condition and therefore could not notify the employer of it, nor seek reasonable accommodation. ${ }^{70}$ The employee also claimed that the employer was on notice of the mental disability by virtue of the employee's conduct.71 The court did not accept this argument, stating that the employer is obliged to accommodate only those disabilities that are obvious or called to its attention by the employee. The court determined the employer is not obliged at its peril to determine whether the behavior was the product of a disability. ${ }^{72}$ Similarly in Fenton $v$. Pritchard, 73 the plaintiff claimed he should have been protected from dismissal because his employer "knew" he was "mentally impaired." In this case, the plaintiff harassed a female co-worker because he wanted to have a relationship with her. When he was spurned, he followed her and sent her threatening notes. ${ }^{74}$ The female complained to her supervisors and the plaintiff was warned numerous times that his advances were affecting the workplace. After an encounter in which the plaintiff slapped the woman outside of her

66 Id.

6729 C.F.R. Pt. 1630, App. (1996); see also 29 C.F.R. § 1630.14(c) (1996).

68889 F. Supp. 133 (S.D.N.Y. 1995).

69 Id. at 134-35.

70 Id.

$71_{\text {Id. at }} 135$.

72889 F. Supp. 133 (S.D.N.Y. 1995).

73926 F. Supp. 1437 (D. Kan. 1996).

74 Id. at 1441-42. 
apartment, the plaintiff was fired.75 In finding no ADA protection, the court commented that even though the defendants believed the plaintiff could be violent, that did not translate into a belief that the plaintiff was disabled. The court stated that the plaintiff "would have this court ignore objectionable behavior and instead impute to [plaintiff] this contrived theory of mental disability."76

Decisions protecting the employee are rare, however, the plaintiff in Collins v. Blue Cross Blue Shield of Michigan, 77 prevailed on a theory of discrimination despite not seeking an accommodation for a disability. In Collins, the plaintiff took medical leave for stress and began psychiatric treatment for major depression/adjustment disorder. During her psychotherapy, the employee made the following statements about her supervisor: "She is living on borrowed time and she doesn't know it"; "I have killed her a thousand times in my mind."78 Based on the report of these statements, the employee was terminated after she was released to return to work by the treating psychiatrist. In finding for the employee, the court stated that the statements were not made in the workplace and were products of her psychiatric disability. Thus, the statements were not workplace misconduct and not a proper basis for lawful termination. ${ }^{79}$ As such, the court found, "terminating her on the basis of the statements was equivalent to terminating her because of her disability." 80 The employee was found entitled to ADA protection.

\section{ESSENTIAL JOB FUNCTIONS}

If an individual has a legitimate disability and that disability creates a barrier to employment opportunities, the ADA requires employers to consider whether reasonable accommodation could remove the barrier. ${ }^{81}$ However, while the ADA focuses on removing barriers, it does not relieve a disabled employee from the obligation of performing "essential job functions" as opposed to marginal job functions. 82 The EEOC Appendix and the Technical Assistance Manual provide examples of what are to be considered essential job functions; however, both make clear that an essential job function is defined by the particular job and that an "essential" function may change from job to job. 83

\footnotetext{
$75 \mathrm{Id}$.
}

76 Id. at 1445.

77916 F. Supp. 638 (E.D. Mich. 1995).

78 Id. at 640 .

79 Id. at 643 .

80 Id.

8129 C.F.R. $\$ 1630.9$ (1996).

8229 C.F.R. $\$ 1630.2(\mathrm{n})(1)$ (1996).

8329 C.F.R. § 1630, App. (1996); EEOC Tech. Assistance Manual par. 100,120, 100,113-15 (1994). 
The Appendix defines essential functions as "those functions that the individual who holds the position must be able to perform unaided or with the assistance of a reasonable accommodation." 84 It discusses three factors that are generally considered.85 The first is whether the position exists to fulfill a particular function. 86 The second is whether there are other employees to whom the function can be distributed and still have the function be accomplished 87 The third factor is the degree of expertise or skill required to perform the function. 88 The employer's judgment as to what is essential to performance of the job is relevant to the inquiry, but is not conclusive. ${ }^{89}$ Also, the business judgment of the employer will be given deference with regard to production standards. ${ }^{90}$ In the end, the EEOC states that the determination of essential job functions is a factual determination that must be made on a case-by-case basis. ${ }^{91}$ Courts have also made various determinations as to what should be considered "implicitly essential" job functions. Since these are neither articulated by statute or regulation, "implicitly essential" job functions are somewhat fluid and their existence may depend on the particular employment situation. Some implicitly essential functions are that employees must be amenable to supervision and must have the ability to follow the orders of supervisors. 92 Employees must also be able to control behavior on the job, and to refrain from engaging in physical violence while at work.93 The ability to understand ordinary pressures of the job has been found "implicitly essential." 94 In addition, it has been held that "regular and predictable" attendance is an implicit job requirement. 95

8429 C.F.R. $§ 1630$, App. (1996).

85 Id. The three factors are explications of 29 C.F.R. $\$ 1630.2(\mathrm{n})(\mathrm{i})$-(iii) (1996).

8629 C.F.R. $§ 1630.2(\mathrm{n})(\mathrm{i})$ (1996); see also 29 C.F.R. § 1630, App. (1996).

8729 C.F.R. $\S 1630.2$ (n)(ii) (1996); see also 29 C.F.R. § 1630, App. (1996).

8829 C.F.R. $§ 1630.2$ (n)(iii) (1996); see also 29 C.F.R. § 1630, App. (1996).

${ }^{89}$ See EEOC Tech. Assistance Manual par. 100,120, 100,114 (1992): "An employer's judgment as to which functions are essential is important evidence. However, the legislative history of the ADA indicates that Congress did not intend that this should be the only evidence, or that it should be the prevailing evidence. Rather, the employer's judgment is a factor to be considered along with other relevant evidence." Id.

90 Id.

9129 C.F.R. $\$ 1630$, App. (1996).

92 See, e.g., Mancini v. General Elec. Co., 820 F. Supp. 141 (D. Vt. 1993); see also Adams v. Alderson, 723 F. Supp. 1531 (D.D.C. 1989).

93Palmer v. Circuit Court of Cook County, 905 F. Supp. 499 (N.D. Ill. 1995); Mazzarella v. United States Postal Serv., 849 F. Supp. 89 (D. Mass. 1994).

94 Pesterfield v. Tennessee Valley Auth., 942 F.2d 437 (6th Cir. 1991).

95 Tyndall v. National Educ. Ctrs., 31 F.3d 209 (4th Cir. 1994); Carr v. Reno, 23 F.3d 525 (D.C. Cir. 1994); Walders v. Garrett, 765 F. Supp. 303 (E.D. Va. 1991). 


\section{REASONABLE ACCOMMODATION}

The EEOC Appendix defines an accommodation to be any change in the work environment or in the way things are customarily done that enables an individual with a disability to enjoy equal employment opportunities. 96 Beyond that, the EEOC Appendix discusses possible accommodation as a reallocation of non-essential job functions, as well as transferring employees to other jobs within the organization.97 The EEOC Appendix states that transferring may not be used to limit and segregate disabled workers from others, and also that employers need only consider transferring to vacant positions as opposed to creating positions. 98 There is no discussion of or requirement to displace other employees in order to accommodate the disabled employee.

The Code of Federal Regulations also suggests possible accommodations such as job restructuring, re-assignment to vacant positions, and modified work schedules, but does not detail any specific mandatory accommodations. ${ }^{99}$ In essence, the only requirements are that the employer and the employee engage in an informal, interactive process of determining the appropriate accommodation for the particular individual. 100 The lack of precision is not helpful to employers or employees, but is most likely the result of an attempt to cover many individualized circumstances and to include as many individuals as possible.101

There are various cases that have discussed what would not be a reasonable accommodation. In Adams $v$. Alderson, 102 the court held that even if disruptive conduct could be traced to a compulsive personality disorder, federal law did not require that the plaintiff be reasonably accommodated by being separated from the supervisor with whom he had a personality conflict. This was also the case in Mazzarella $v$. United States Postal System,103 in which the court stated, "It is not reasonable, however to expect the [employer] to juggle personnel so as to entirely remove the possibility that a supervisor may offend a particular employee." The court in Hogarth $v$. Thornburgh, 104 found that it was not reasonable to accommodate an FBI employee by having his medical treatment monitored, or temporarily restricting his access to confidential documents.

\footnotetext{
9629 C.F.R. $§ 1630$, App. (1996).

97 Id.

98Id.

9929 C.F.R. §1630.2(o) (1996).

10029 C.F.R. $\S 1630.2($ o)(3) (1996).

101 See EEOC Tech. Assistance Manual par. 100,120, 100,112 (1992).

102723 F. Supp. 1531 (D.D.C. 1989).

103849 F. Supp. 89,96 (D. Mass. 1994).

104833 F. Supp. 1077 (S.D.N.Y. 1993).
} 
Reiterating the reasoning of School Bd. of Nassau County v. Arline, 105 the Hogarth court determined that reasonable accommodations did not include finding another job for a person who could no longer perform his or her own job.106

\section{OTHERWISE QUALIFIED}

Although "otherwise qualified" is a prima facie showing prior to demonstrating an essential job function can be performed with reasonable accommodation, the term is problematic when assessing how mental illness affects job qualification after hire. When a mental condition has been diagnosed, is it possible that a worker can engage in behavior that makes him no longer be qualified for the job? The courts have answered this question inconsistently. In some cases, an act of violence or possession of a weapon is sufficient to negate qualification and justify termination without violating ADA standards. 107 In other cases, the employer may be required to retain the employee because the unacceptable behavior is a symptom of a legitimate mental illness. 108

For example, in Matzo v. Postmaster General, 109 the plaintiff-employee was a stenographer who had been employed with the United States Postal Headquarters for ten years. During the last three years on the job, her job performance deteriorated as the result of intermittent episodes of "erratic, disruptive, and insubordinate" behavior. 110 The employee subsequently notified her employer that she had been diagnosed with manic-depressive illness. The employee remained on the job, but with no improvement in behavior. She was issued a letter of warning, after which she left the office without permission and did not return. Several weeks later, the employee did not respond to a notice to report for a fitness-for-duty exam and she was subsequently terminated. The employee claimed the termination was predicated on the fact that she was diagnosed as a manic-depressive. ${ }^{111} \mathrm{In}$ seeking status as an "otherwise qualified person," the employee claimed that her disability was controllable by medication and was in remission. The court

105480 U.S. 273 (1987).

106833 F. Supp. at 1088.

${ }^{107}$ See Franklin v. United States Postal Serv., 687 F. Supp. 1214 (S.D. Ohio 1988)(lawful termination for possession of a weapon despite diagnosis of paranoid schizophrenia), but cf. Hindman v. GTE Data Serv., Inc., No. 93-1046-CIV-T-17C, 1994 WL 371396 (M.D. Fla. June 24, 1994)(unlawful termination for possession of a weapon with diagnosis of chemical imbalance).

108 Hindman, 1994 WL 371396.

109685 F. Supp. 260 (D.D.C. 1987).

$110 \mathrm{Id}$. at 261.

111 Id. at 263. 
disagreed stating that her inability to report to work made her unqualified for a position that required employees to show up for work.112

Similarly, in Franklin v. United States Postal Service, the employee had a record of an "unfavorable and belligerent attitude towards her co-workers and towards the public." 113 Off the job, she had been arrested for fraud, assault, and disorderly conduct. Her illness was diagnosed as paranoid schizophrenia. After appearing with a concealed weapon at the state governor's office, she was terminated from her job. The employee claimed discrimination based on the fact that her behavior was a symptom of her mental illness and as such could not be a legal basis for termination. 114 In response, the court decided that since there was evidence that the employee could control her symptoms by medication and at times chose not to medicate herself, the absenteeism was not a symptom of her illness. 115 The court also reasoned that a person with a history of anti-social behavior whose condition of paranoid schizophrenia is not controllable by medication (or otherwise) is a danger to the public and to co-workers. Consequently, that person is not an "otherwise qualified" individual. 116

More recently, in Greenberg $v$. New York State, 117 an applicant for the position of Corrections Officer was denied employment because the pre-employment psychological exam revealed that he was unable to perform efficiently under stress. He also lacked the ability to make sound safety and security decisions in emergency circumstances. The plaintiff then brought suit under the Americans with Disabilities Act. In finding against the plaintiff, the court determined that since the plaintiff did not have a diagnosed mental disorder, but merely did not have the personality attributes required for the particular job, he did not warrant protection under the ADA.118

Hogarth $v$. Thornburgh, 119 represents the most favorable analysis finding an employee "otherwise qualified," despite ultimately determining that no reasonable accommodation could be made. In Hogarth, the plaintiff was a clerk

112Id. The Matzo court sidestepped consideration of the fact that the employee's inability to work, or any of her other behavior, was symptomatic of her disability. The disruptive behavior was not a key fact in the determination. However, the court could have characterized the disruptive behavior as an example of violation of work rules, which would justify termination. On the other hand, these behaviors could be symptomatic of a manic-depressive illness which arguably protected behavior and requires accommodation.

113687 F. Supp. 1214, 1219 (S.D. Ohio 1988).

${ }^{114} I d$.

115 Id.

116 Id.

117919 F. Supp. 637 (E.D.N.Y. 1996).

118 Id. at 643 .

119833 F. Supp. 1077 (S.D.N.Y. 1993). 
with the FBI, who was diagnosed with manic-type bi-polar disorder. His irregular behavior included submitting a fraudulent doctor's excuse for a back injury and having homosexual relations at work. He was terminated based on this behavior. The plaintiff presented medical testimony which linked the acts for which he was terminated to the diagnosed mental disorder. ${ }^{120}$ The FBI defended the termination by stating that the lack of reliability and stability exhibited by the employee justified disqualification for the security clearance required for all FBI employees. 121 The court engaged in an extensive analysis of the "otherwise qualified" definition.122 The court pointed out that if a disability manifests itself in certain behavior which is used as a reason for discharge, then there is actionable discrimination. 123 To illustrate this point, the court analogized the situation to one in which an individual with a limp is fired for the "thumping sound" made when he walks, or the employee with epilepsy who is fired for his seizures. 124 Otherwise, the court explained, employers would be able to claim lack of awareness of the link between the disability and its manifestations. 125

In a similar case, the court of Hindman v. GTE Data Services, Inc., 126 considered an employee diagnosed with a "chemical imbalance" which required hospitalization. Within several days, the employee returned to work carrying a concealed weapon in violation of a work rule. 127 The employer cited this work-rule infraction as just cause for termination. In response, the employee alleged discrimination due to a mental handicap, explaining that the poor judgment displayed in choosing to carry the concealed weapon was merely a symptom of the chemical imbalance and not evidence of deficient character. A right to continued employment was claimed under the ADA and granted pending a mental health evaluation to determine whether the behavior could be attributed to the illness, thus making the employee "otherwise qualified" to perform his job.

$120 I d$. at 1082 .

121 Id.

122 Id. at 1084 .

123833 F. Supp. at 1085.

124 Id.

125Id. According to the court in Hogarth, all employees at times fail to perform their job functions. For a person with a disability, two factors determine whether the person is qualified for a position despite a disability. One issue to consider is the consequences of a failure to perform. The other issue is the likelihood that the failure is caused by the disabling condition. With this reasoning, the court opened up the possibility that certain behaviors are protected and will continue to be protected until the cause of a behavior can be determined. If the behaviors are caused by mental illness, the employee would be protected and may be kept on the job with accommodation.

126No. 93-1046, Civ-T-17C (M.D. Fla. June 24, 1994).

127 Id. at $* 2$. 


\section{DIRECT THREAT OF HARM}

According to the ADA and corresponding regulations, employers are not mandated to keep employees in the workplace who pose a direct threat of harm to the health or safety of an individual or others, if no accommodation can mitigate the risk. ${ }^{128}$ To identify the potential for harm, an assessment of the individual's present ability to safely perform the essential functions of the job must be "based on reasonable medical judgment that relies on the most current medical knowledge...."129 The risk posed by allowing the individual into the workplace must be significant and contain a high probability of substantial harm. ${ }^{130}$ The EEOC Appendix directs that the threat of harm must be based on "individualized, objective evidence." 131 Most of the Congressional and EEOC discussion about "threat of harm" relates to employees with communicable diseases, such as HIV.132 There is no discussion relative to the threat of harm posed by mentally ill employees who may be prone to violence.

The majority of the cases which involve mentally-disabled employees who engage in workplace violence have been resolved by summary judgment in favor of the employers, because the employees have failed to make out a prima facie case of discrimination. The stumbling block for most plaintiffs has been the inability to prove either that the employee is disabled within the meaning of the statute, or that the employee is "otherwise qualified" and able to perform the essential job functions without accommodation or with some reasonable accommodation provided by the employer. ${ }^{133}$ Because of the failure to state a viable cause of action, the question of whether the employer has a defense of the "direct threat of harm" has rarely been considered in workplace violence or disruption situations. ${ }^{134}$ A case that did consider "direct threat of harm," Kohnke v. Delta Airlines, 135 decided in 1996, determined that discharge for a direct threat of harm applies only when others are threatened, not just when a person is self-destructive. 136 This case has had no bearing on the development of law

12842 U.S.C. $§ 12113$; see also 29 C.F.R. $\$ 1630.2$ (r); 29 C.F.R. $\$ 1630$, App. (1996).

12929 C.F.R. $\S 1630.2(r)$ (1996).

130 Id.

13129 C.F.R. $\$ 1630$, App. (1996).

132H.R. Rep. No. 485(III), 101st Cong., 2d Sess. 45-46 (1990).

133 See supra notes $62-118$ and accompanying text.

${ }^{134}$ Rizzo v. Children's World Learning Ctr., 84 F.3d 758 (5th Cir. 1996) considered direct threat of harm in relation to a hearing impaired bus driver's potential to "harm" children by not hearing choking at the back of the bus.

135932 F. Supp. 1110 (N.D. Ill. 1996).

136 The manner in which the case law has developed makes the "direct threat" aspect practically irrelevant. It would seem that the only instance in which this aspect of the regulations would make an impact is when an applicant for a job reveals that he has been diagnosed with a mental disorder. In this case, an employer could not refuse to hire the applicant on the basis of generalized fears that persons with that mental disorder 
concerning what evidence demonstrates a direct threat of harm to others, although one could speculate that threatening people and carrying a weapon at work would suffice to constitute a direct threat of harm.

The "direct threat" aspect of the statute represents its own incongruities with what are the intentions of the ADA. While the statute allows for a dismissal to be made when there is a direct threat of harm, the statute forbids direct inquiry as to an employee's mental condition and does not address the statute's application when the direct threat of harm be a manifestation of a legitimately diagnosed mental illness. This puts the employer in the intriguing position of being in compliance with the law to dismiss a potentially violent person (under the rationale the employee is not qualified) than it would be to encourage solving a problem with suggesting psychological or psychiatric help.

\section{THE FUTURE OF MENTAL DisABILITIES UNDER THE ADA: SUGGESTIONS FOR CHANGE}

Overall, the Rehabilitation Act, ADA, and the EEOC's interpretative guidelines provide employers with few specifics outlining legal obligations to mentally-disabled persons. Although it is abundantly clear that employers win most actions brought under the $\mathrm{ADA}$, the analysis used by courts to reach these decisions is not uniform. Some courts have focused on the lack of notice to employers. Other courts have found disruptive behavior equal to an inability to perform an essential or implicitly essential job function. Other courts have found those with certain personality quirks automatically unqualified under the statututory definitions, while other courts have ultimately determined that engaging in certain on-the-job behaviors will make an individual unqualified. Courts have made these decisions even when the behavior resulting in termination was the product of a legitimate mental illness. Based on these decisions, even employers familiar with case law do not know exactly what situations are covered under the Act.

One can assume there is a certain wisdom in the vagueness in the statute. The EEOC Tecnical Assistance Manual states, "Neither the statute nor EEOC regulations list all diseases or conditions that make up 'physical or mental impairments,' because it would be impossible to provide a comprehensive list, given the variety of possible impairments." 137 If the statute specifically articulated those mental illnesses protected, it would invariably leave out others that should legitimately be included. However, as knowledge of behaviors increases, the statute should be adapted to reflect increases in knowledge. The statute should not be a license to discriminate by virtue of too

are prone to violence. Instead, the action would have to be predicated on particularized objective evidence of prior acts of violence or misconduct, or a medical opinion which states that the applicant is likely to engage in imminent violence. For a discussion of these issues, see Mary E. Sharp, The Hidden Disability that Finds Protection under the Americans with Disabilities Act: Employing the Mentally Impaired, 12 GA. ST. U. L. REV. 899 (1996).

137EEOC Tech. Assistance Manual par. 100,120, 100,108 (1992). 
much specificity, but the Act should do more in order to clearly apprise employers of their obligations while apprising employees of their rights. Clarity and specificity within the law would also hinder abuse by those who were not intended to be protected.

Caselaw demonstrates that a suit for discrimination after termination is likely to be unsuccessful absent a mental health professional's diagnosis. Given this reality, the statute should be amended to include a provision stating that those seeking accommodation for mental disability (and subsequently bringing action for lack of accommodation) must submit a documented mental health evaluation to their employer. The mental health evaluation should include what the professional would believe to be a reasonable accommodation and an approximate time frame (even if indefinite) for how long the reasonable accommodation would have to be made. Requiring documentation under the statute would allow courts to dismiss suits in which the discharged employee asserts an undiagnosed ailment and then attempts medical validation after dismissal. It would also eliminate the need for employers to guess what legally should be done, with employees exhibiting anti-social behavior. Without medical validation presented by the employee to the employer, the employer would be free to assess the anti-social employee in the context of other anti-social employees without the fear of making a decision that would violate the Act.

In addition, the statute should be amended to absolve an employer from liability for asking about a disability, or should more clearly apprise the employer when it is obligated to inquire whether an individual requires an accommodation. Under current law, it is not clear whether an employer may ask about a specific disability unless that disability is "obvious."138 Given that mental disabilities are rarely obvious, 139 the statute should also be amended to preclude employers from liability for discharging an employee who does not have an illness diagnosed until after termination. If employers are prevented from asking overt questions, they should be explicitly absolved from having the responsibility for detecting mental illness by way of behavior, and suggesting that an employee seek a diagnosis.

While these revisions might remedy situations in which employees allege wrongful termination because no reasonable accommodation was made, these revisions will not remedy complications associated with employees alleging discrimination because of a "record of impairment" or because of being "regarded as impaired." The original purpose of these descriptions was to ensure that recuperated individuals or those functioning well with a legitimate handicap would not be discriminated against on the basis of misperception. 140

${ }^{138}$ Thompson, supra note 11 , at 54 .

139 Id.

140 See Arline, 480 U.S. at 283: "By amending the definition of "handicapped individual" to include not only those who are actually physically impaired but also those who are regarded as impaired and who, as a result, are substantially limited in a major life activiity, Congress acknowledged that society's accumulated myths and fears about 
While these descriptions might originally have contemplated physical disabilities, for instance, the misperception that a person with a bad scar would not be accepted by the general public as a store clerk, 141 it is conceivable that misperceptions about mental illness might result in the same type of prejudice. A recovered alcoholic might be passed up for promotion because of a fear of future behavior; a person currently taking anti-depressants might not be put into what are perceived to be stressful situations.

These individuals would not need medical certification because, theoretically, they would not be seeking accommodation in the workplace. Yet the potential for discrimination is still there. In fact, allegations of prejudice on the basis of "being treated as mentally impaired" has been a prevalent claim in ADA (mental disability) litigation and probably possess the potential for abuse. 142

Perhaps the best way to address the situation is not an amendment that would more specifically define "record of impairment" and "regarded as impaired," but rather an amendment that would state what these terms do not include. Within the sphere of mental disability litigation, courts have concurred that "regarded as impaired" does not mean "a perceived, undiagnosed disability." This language could be incorporated into the definitions for disability. For example:

The term "disability" means, with respect to an individual- . . .

(B) having a medical record for treatment of a mental or physical disability, or

(C) currently receiving medical treatment for a mental or physical disability

The term "disability" does not include a "perceived undiagnosed ailment."

In this way, there is still an acknowled gment that an individual being treated for a mental disability might be discriminated against without the need for that individual to provide medical documentation prior to an employment incident. The amendment would, however, make clear that documentation of the mental disability must exist in some sphere. This would theoretically prevent employees from using the ADA to protect them from termination when the only allegation is that they were "perceived" as disabled.

In addition, both the EEOC interpretive guidances and/or the Technical Assistance Manual might also be modified to include provisions explaining both the rights and obligations of employees. The manual might set forth some uniform employment provisions detailing an employee's rights under the ADA and explaining that the procedure for substantiating a future claim entails a written diagnosis of a mental health professional submitted prior to a

disability and diseases are as handicăpping as are the physical limitations that flow from actual impairment."

141 See EEOC Tech. Assistance Manual par. 100,120, 100,112 (1992).

142 See George Will, Editorial: Disabilites Act may end up Granting Special Rights to Jerks, IDAHO Statesman, Apr. 4, 1996. 
complaint or lawsuit. Such model language would not be unprecedented. The federal government has recently formulated model language for various, federally regulated, pension disbursement agreements, ${ }^{143}$ and most (if not all) states have statutorily required language for many consumer contracts. ${ }^{144}$ In fact, the Technical Assistance Manual does contain suggested employee handbook provisions, but these provisions tend only to include the information that the employer is, in fact, bound by the criteria of the ADA.145 These provisions should be enhanced to explain the statute, and it would not be out of the question to suggest that some of these model provisions be statutorily required.

While all employers might not feel comfortable giving their employees the ammunition to be able to file a discrimination claim, such uniform provisions would actually be beneficial to both employers and employees. Theoretically, employers and employees would understand their obligations and outcomes would not be subject to the changing tone of the court system. Costly litigation could be avoided on both ends. An indirect positive result might be more awareness of mental health, and the need to seek appropriate treatment prior to losing employment or an opportunity for promotion. 146

Additionally, the ADA should acknowledge that a mental disability may require different standards and accommodations than a physical disability. Whether the statute was intentionally vague or whether mental health is too evolutionary to develop specific guidelines for protecting the mentally-disabled, the statute inappropriately makes physical impairment nearly synonymous with mental impairment. This has lead to incongruent analogies as plaintiffs have attempted to engraft case law examining discrimination against the physically disabled onto situations where there is

143 See, e.g., I.R.S. Notice 97-10: Sample Language for a Spouse's Waiver to a QISA or a QPSA; I.R.S. Notice 97-11: Sample Language for a Qualified Domestic Relations Order.

${ }^{144}$ See, e.g., Colo. REv. ST. ANN. 6-1-203 (West 1997)(mandatory language to be included in offer of collision damage waiver purchase); DEL. CODE ANN. tit. $25 \S 5715$ (West 1997)(mandatory language for writ of possession); FLA. ST. ANN. $\$ 627.7263$ (West 1997)(mandatory notice that personal insurance covers rental vehicles); MINN. ST. ANN. \$325F.692 (West 1997)(mandatory notice to be included on phone bills); OR. REV. STAT. $\S 94.983$ (West 1997) (mandatory notice of opportunity to cancel "membership camping contract.") WASH. REV. CODE ANN. $\$ 19.105 .390$ (West 1997)(mandatory notice of opportunity to cancel resort contract).

${ }^{145}$ EEOC Tech. Assistance Manual par. 130,001 et seq. (1992).

146 "A recent Epidemiologic Catchment Area (ECA) study suggests that over $28 \%$ of American adults have a diagnosable mental disorder in a given year. This same study reveals that $14.7 \%$ of American adults-more that 23 million people-sought treatment for mental or addictive disorders in one year." See Thompson, supra note 11, at 26 (citing Darrell A Regier et al., The de Facto U.S. Mental and Addictive Disorders Service System: Epidemiologic Catchment Area Prosepective 1-Year Prevalence Rates of Disorders and Services, 50 ARCH. OF GEN PSYCHIATRY 85, 88 (1993) and Evelyn J. Bromet, et al., Epidemiology of Depression and Alcohol Abuse/Dependence in a Mangerial and Professional Work Force, $32 \mathrm{~J}$. OCCUPATIONAL MED. 989, 992 tbl. 1 (1990)). 
an alleged mental disability. 147 It is one thing to find obvious the need for a wheelchair ramp, but another to expect an employer to recognize and appropriately accommodate a psychiatric disorder. Some of the inappropriate comparisons could be alleviated by revising the ADA to separate definitions and analysis between physical impairments and mental impairments. While there is arguably overlap in some cases, an overt acknowledgment that some categories of mental disabilities are not at all appropriate for physical disability analysis would aid in the development of clear expectations for both employers and employees.

\section{CONCLUSION}

The Americans with Disabilities Act has been an appropriate first step in recognizing the possibility for discrimination against those with unseen mental disabilities. However, because the statute and corresponding regulations do not address mental disabilities with any amount of specificity, litigation under the statute has resulted in a validation of nearly all employer firing decisions. Additionally, this litigation has resulted in employees pursuing "novel" theories of protection that were often predicated on perceptions rather than on legitimate medical diagnoses. A revision of the statute and regulations that acknowledges the difference between physical disability and mental disability detailing acceptable methods for validating a disability claim would be beneficial to both employers and employees. Both parties would be on notice of rights and responsibilities. The end result would hopefully be courts grappling less with defining those rights and responsibilities, and fairer outcomes for those legitimately discriminated against.

${ }^{147}$ Such as the notion of discrimination based on the "perceived disability." 
HeinOnline -- 11 J.L. \& Health 194 1996-1997 